\title{
Nanism (dwarfism) in fish: a comparison between red mullet Mullus barbatus from the southeastern and the central Mediterranean
}

\author{
Oren Sonin ${ }^{1}$, Ehud Spanier ${ }^{2, *}$, Dino Levi ${ }^{3}$, Bernardo Patti ${ }^{3}$, Pietro Rizzo ${ }^{3}$, \\ Maria Gabriella Andreoli ${ }^{4}$ \\ ${ }^{1}$ Ministry of Agriculture and Rural Development, Department of Fisheries and Aquaculture, The Agricultural Center, \\ PO Box 30, Beit Dagan 50250, Israel \\ ${ }^{2}$ The Leon Recanati Institute for Maritime Studies and the Department of Maritime Civilizations, University of Haifa, \\ Mount Carmel, Haifa 31905, Israel \\ ${ }^{3}$ Istituto di Ricerche sulle Risorse Marine e l'ambiente (IRMA) —CNR, Via Vaccara 61, 91026 Mazara del Vallo (TP), Italy \\ ${ }^{4}$ Instituto di Istologia ed Embryologia, Universitá di Palermo, Via Archirafi 22, 90123 Palermo, Italy
}

\begin{abstract}
The gradient of environmental conditions from west to east in the Mediterranean results in very low primary productivity in the eastern area of this sea. This impoverishment is expressed also in higher trophic levels and has been accounted for by several faunistic phenomena. One of these is 'Levantine nanism' (dwarfism); this is characterized by smaller body size of specimens in the Levantine basin compared with conspecifics in the western Mediterranean. Nanism has been hypothesized for various taxonomic groups in the Mediterranean, but no quantitative study has yet been carried out to confirm it. In the present study male and female red mullet Mullus barbatus from trawl surveys carried out along the Mediterranean coast of Israel and the Strait of Sicily were sampled. Each fish was sexed, measured for total length (TL) and aged by otolith readings. ANCOVA analyses indicated that the TL of both males and females from Israel was significantly smaller at increasing ages than conspecifics of the same age and sex from Sicily. In addition, preliminary examination of sexual maturity of $M$. barbatus of both sexes indicated that the Israeli fish sexually mature at a smaller size than conspecifics of the same sex from Sicily. These findings can be explained by low productivity in the Levantine basin compared with the western Mediterranean. The low and unpredictable food supply in the southeastern Mediterranean may result in a form of r-strategy of the marginal eastern populations of this species that leads to early reproduction and smaller body size. The average higher water temperature may also partly explain Levantine nanism, as it may cause more intensive metabolic processes in the southeastern population, resulting in earlier sexual maturity and cessation of growth.
\end{abstract}

KEY WORDS: Nanism $\cdot$ Dwarfism $\cdot$ Total length $\cdot$ Sexual maturity $\cdot$ Otolith readings $\cdot$ Small body size Mediterranean Sea $\cdot$ Mullus barbatus

\section{INTRODUCTION}

The Mediterranean Sea is generally considered to be the most impoverished large body of water known (Ryan 1966); it is characterized by a gradient of changing environmental conditions from west to east: chemical, physical and biological.
As water salinity and temperature increase and nutrient content decreases, productivity in the eastern Mediterranean declines compared with that in the western and central areas of this sea (e.g. Saurnia 1973, Azov 1986, Herut et al. 2000). This impoverishment is expressed in several faunistic phenomena. Foremost among them is a decrease in the number of species of 
some taxonomic groups in the eastern Mediterranean compared with those found in the central and western areas of this sea (Por 1989). Ben-Tuvia (1983) calculated that the Levant basin in the southeastern Mediterranean contains only $57 \%$ of the fish species of the western Mediterranean, although this finding has been questioned by Goren \& Galil (1997), at least in regard to deep sea fishes in the Levant. Golani $(1996,2005)$ and Quignard \& Tomasi (2000) listed 410 fish species in the Levant, 511 species in the central Mediterranean and 638 in the western Mediterranean. Goren \& Galil (1997) calculated that the ichthyofauna of the Levant represents $63 \%$ of the species of bony fish found in the western Mediterranean. This aspect has been well studied due to careful censuses of Mediterranean fauna (e.g. Fredj \& Laubier 1985, Fredj \& Maurin 1987).

Another important biological phenomenon, apparently associated with the impoverishment of the eastern Mediterranean, has been hypothesized by Por (1989), i.e. 'Levantine nanism,' which involves small body size (dwarfism). He suggested that nanism might be the result of exceptional environmental factors (high salinity and temperature), low productivity, or of a combination of all these aspects. Por further proposed that nanism is a special expression of $\mathrm{r}$-strategy, in populations of species that are at the margins of their zoogeographical distribution. Nanism had been suggested for various taxonomic groups: by Levi (1957) for sponges, by Stephen (1958) for sipunculids, by B. Galil (pers. comm. 1998) for crustaceans, for coelenterates by M. Fine (pers. comm. 2002), and for polychaetes by Laubier (1966). Ben-Eliyahu \& Fiege (1994) found that specimens of polychaetes Euarche tubifex (family Acoetide $=$ Polyodontidae) from the Israeli coast were significantly smaller in length than those collected along the Sicilian coast. However, age information for the specimens was lacking, and the depth ranges of the samples were different, with the Israeli population coming from a broader depth range.

In bony fish, Tortonese (1951) indicated the same trend. Scientists, who recently compared commercial fishes of the family Sparidae from the Mediterranean coast of Israel with conspecifics sampled in the western Mediterranean and the Atlantic, were impressed by how much larger the western specimens proved to be (M. Tom \& L. Fishelson pers. comm. 2002).

Referring to benthic fauna, Pérés \& Picard (1956a,b,c, 1958) mentioned that the specimens of species common in the entire Mediterranean were clearly smaller in the eastern part of the basin than those collected in the west. They suggested that nanism might be related to a lower prevalence of food in the east. More likely, as they and Wirssubski (1953) assumed, since the average water temperature in the southeastern Mediterranean is higher than in the west, conspecifics in the east exhibit intensive metabolism. This enhanced metabolism results in earlier sexual maturity and a deceleration of growth.

In ectotherms, age and size at maturity typically decrease with an increase in temperature (e.g. Dhillon \& Fox 2004 and review by Atkinson 1994), resulting in a slowing down of growth. This inverse relationship between temperature, age and size at maturity has been explained using environmental-physiological arguments (e.g. van der Have \& de Jong 1996, Atkinson \& Sibly 1997) and rationalized from the perspective of life-history theory (e.g. Berrigan \& Charnov 1994, Sibly \& Atkinson 1994).

In order to confirm the nanism hypothesis, a systematic, quantitative comparison of sex, age and sexual maturity between specimens from the western-central part of the Mediterranean and conspecifics from the eastern part is required. As a first of its kind, the present study aimed at making exactly such a comparison. We selected red mullet Mullus barbatus as a comparative subject. Red mullet is one of the most commercially important species found throughout the Mediterranean (Whitehead et al. 1986). Specimens of this species can be found in commercial yields throughout the year and can be sampled during commercial and scientific fishing cruises. As a result of this, along Mediterranean coasts, the red mullet and some of its biological and ecological characteristics have been studied extensively over the years.

Mullus barbatus is a benthic species frequently found on muddy seabeds in a depth range of 5 to $250 \mathrm{~m}$ (Relini et al. 1999). The reproduction period of $M$. barbatus along the coast of Israel is between March and June (Golani \& Darom 1997) and between May and July in the Strait of Sicily (Relini et al. 1999). The annual fishery yield of red mullet along the Mediterranean coast of Israel is on the order of $300 \mathrm{t}$ (Golani \& Darom 1997, Snovsky \& Shapiro 1999) and $20114 \mathrm{t}$ in Italy (for 1982), of which the Sicilian total catch was 13886 t (Cingolani et al. 1986). However, the most recent (2001) official data indicated a decrease in the Italian annual catch to $10708 \mathrm{t}$, of which the Sicilian catch was 1126 t (IREPA 2000a,b, 2001a,b).

The availability of Mullus barbatus and, more importantly, the extensive experience in otolith readings of this species (e.g. Levi et al. 1994, Sonin et al. 1996) made it a suitable subject species for the present study.

\section{MATERIALS AND METHODS}

Sample collection. Both Israel and Sicily conduct annual trawl surveys on a regular basis. These are one of the sources of data used in making fishing management decisions. All specimens of Mullus barbatus 
caught during the trawl surveys described below were used for the present study and their otoliths were removed for age determination; no sub-sampling was carried out. Total length (TL) measurements are in centimeters, to the accuracy of $0.5 \mathrm{~cm}$.

Strait of Sicily: Specimens of Mullus barbatus from the Strait of Sicily (Fig. 1) were collected during the 23rd trawl survey conducted between October 17 and December 12, 1998, by IRMA-CNR (Istituto di Ricerche sulle Risorse Marine e l'ambiente-National Research Council). This year was selected for the present study since the samples contained representatives of male and female $M$. barbatus from all length groups. The equipment used during the surveys included a commercial trawl net, with a vertical opening of 0.6 to $1 \mathrm{~m}$ and a horizontal opening of 20.9 to $30.3 \mathrm{~m}$. Mesh size in the cod end was $40 \mathrm{~mm}$. Samples were taken mainly between depths of 10 and $200 \mathrm{~m}$. The most common depth range for this species was 50 to $100 \mathrm{~m}$.

A total of 329 specimens, which included all Mullus barbatus sampled in this survey (186 females and 143 males), was taken for otolith readings. Sexual Maturity Stages 2 and 3 (Holden \& Raitt 1974) and total lengths were determined for 162 females and 126 males.
Israel: Red mullet specimens were collected during trawl surveys conducted by the Fishery Department, Israel Ministry of Agriculture, on the Mediterranean continental shelf of Israel (Fig. 1) during May, July, September, October, November and December 2000. The specimens included a range of all length groups. The commercial trawl net used had a vertical opening of 0.8 to $1.3 \mathrm{~m}$ and a horizontal opening of 13 to $14 \mathrm{~m}$. Mesh size in the cod end was $42 \mathrm{~mm}$. Samples were taken between depths of 15 and $230 \mathrm{~m}$. The most common depth range for this species was 50 to $80 \mathrm{~m}$.

A total of 108 specimens (56 females and 52 males), which included all of the Mullus barbatus sampled in these surveys, was taken for morphometric analysis and otolith readings. Sexual Maturity Stages 2 and 3 (Holden \& Raitt 1974) and TLs were determined for 24 females and 27 males.

Otolith readings. Ages of the sampled fish were determined by examining otoliths for annual rings. A critical issue in age determination is validation of the aging technique (Hilborn \& Walters 1992). Determination of fish age by otolith readings is a scientific method that depends on the level of proficiency and experience of the person analyzing. Otoliths analyzed by different readers in separate laboratories may

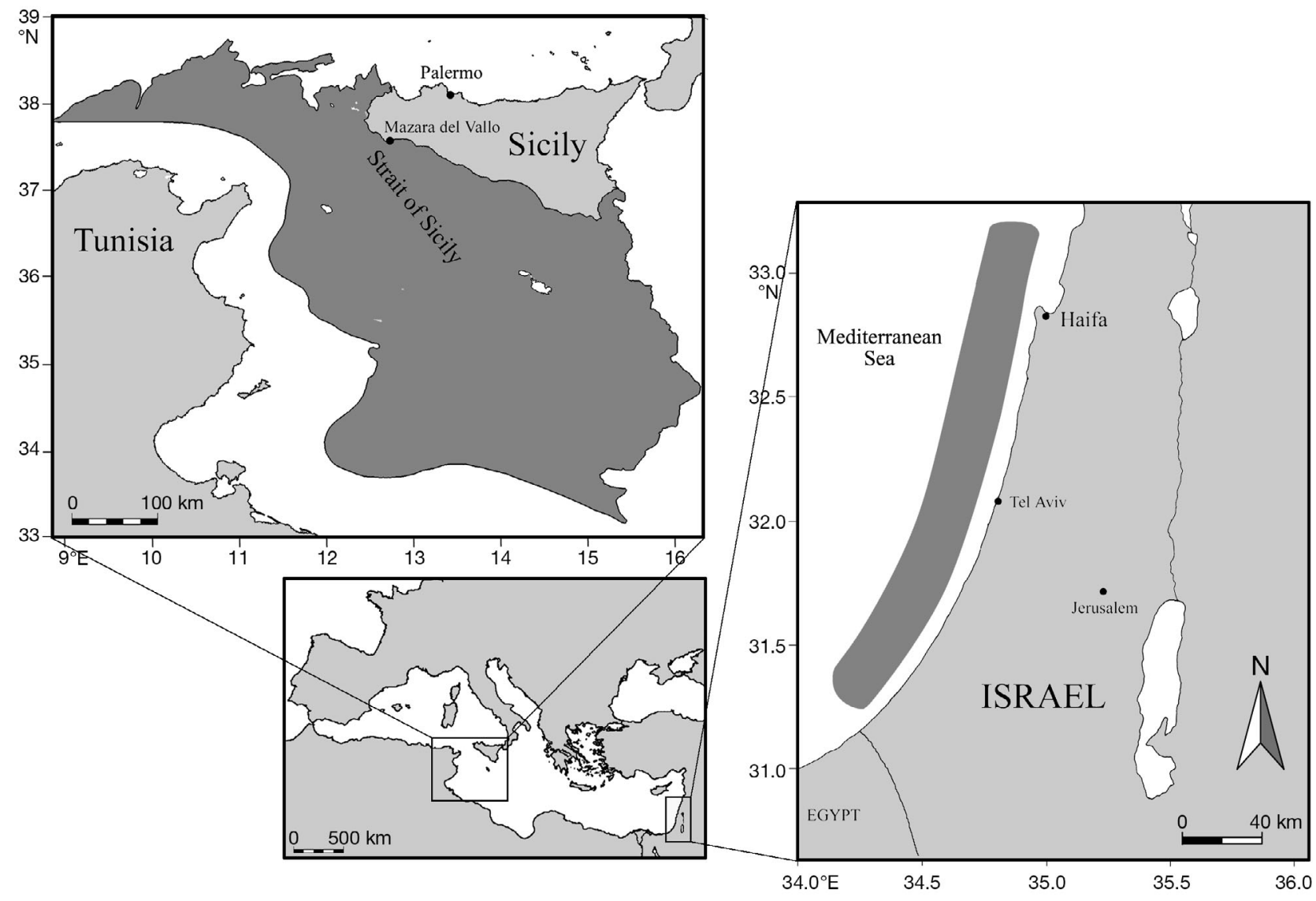

Fig. 1. Study sites in Sicily and Israel. Sampled areas are marked in dark grey 
reveal slightly different results. To prevent such variation from occurring, all fish sampled in Israel and in Sicily were analyzed for otolith annual rings in 1 laboratory (Sicily) by the same 2 readers (Israeli and Sicilian) correspondingly, using a Wild M8 double station binocular. The otoliths were read whole, immersed in ethyl alcohol over a black background.

In the vast majority of readings the decision was mutually agreed upon. Nevertheless, a repeat reading was always performed to assure this. In the few cases where a difference of opinion existed between the readers, a re-examination and further discussion of the case took place. If, even after this procedure, mutual agreement regarding the age reading was not reached, the given otoliths were not included in the final analysis.

Determination of sexual maturity stages. For sexual maturity comparison, a 5 stage system (Holden \& Raitt 1974) was used. Stage 1 represents juvenile specimens with, as yet, no distinction between males and females. In Stage 2, gonads are distinguished easily. In Stage 3, gonads are matured. Spawning takes place in Stage 4; and Stage 5 represents post-spawning.

Data analysis. Analysis of covariance (ANCOVA) was performed to test the differences in TLs between specimens from the 2 areas ('Israel' and 'Strait of Sicily') and thus to detect differences in growth patterns.

Two separate ANCOVA models were fitted for each sex. The dependent variable in the ANCOVA model was the TL. The independent variables were: area (effect), age (covariate) and the interaction between these 2 terms (area $\times$ age). The latter was included to test the equality of slopes of the regression lines representing each area. A significant interaction term supports the occurrence of different growth rates between the 2 areas.

Statistical analyses were carried out using the SPSS v.12 software package.

\section{RESULTS}

\section{Comparison of sizes between the 2 areas}

TLs of Mullus barbatus fished on the Mediterranean continental shelf off Israel were larger than those of their conspecifics of the same age and sex from the Strait of Sicily at Age Class 0 and smaller from Year Class 1 onward (Table 1).

\section{Variation in growth patterns}

For each sex, the overall p-value was highly significant (according to the ANCOVA models; Table 2). Males from Sicily tended to have a significantly longer
Table 1. Mullus barbatus. A comparison of mean total length $(\mathrm{TL}, \mathrm{mm})( \pm \mathrm{SD})$ of males and females from different year classes of from Israel and Sicily. 0: under 1 yr of age

\begin{tabular}{|lcccc|}
\hline \multirow{2}{*}{$\begin{array}{c}\text { Year } \\
\text { class }\end{array}$} & \multicolumn{2}{c}{ Male TL $(\mathrm{mm})$} & \multicolumn{2}{c|}{ Female } \\
& & Sicily & Israel & Sicily \\
\hline 0 & $86.7 \pm 8.8$ & $82.7 \pm 12.5$ & $90.0 \pm 4.5$ & $85.0 \pm 12.4$ \\
1 & $90.0 \pm 9.6$ & $124.0 \pm 12.0$ & $82.9 \pm 10.8$ & $124.7 \pm 11.5$ \\
2 & $128.0 \pm 8.4$ & $156.4 \pm 14.1$ & $126.3 \pm 13.8$ & $154.5 \pm 14.4$ \\
3 & $139.1 \pm 16.6$ & $175.0 \pm 10.6$ & $141.4 \pm 12.3$ & $183.3 \pm 13.7$ \\
4 & $146.2 \pm 14.3$ & $193.3 \pm 11.7$ & $158.2 \pm 16.2$ & $201.7 \pm 8.3$ \\
5 & $146.3 \pm 7.5$ & $195.0 \pm 0$ & $176.0 \pm 11.9$ & $218.1 \pm 9.1$ \\
\hline
\end{tabular}

TL than specimens from Israel at increasing ages (Fig. 2). The p-value of the interaction (age $\times$ area) was marginal, and thus parallel regression lines for each area cannot be excluded.

Females from Sicily likewise tended to have a significantly longer TL than specimens from Israel at increasing ages (Fig. 3). The significant p-value of the interaction (age $\times$ area) suggests the appearance of non-parallel regression lines; thus, growth rates differ between the 2 areas.

\section{Size at maturity stages}

The results of the preliminary examinations of sexual Maturity Stages 2 and 3 in this species (Table 3) indicated that females of Mullus barbatus fished off the coast of Israel reached Maturity Stages 2 and 3 at a smaller size (mean TL: $\sim 136$ and $\sim 143 \mathrm{~mm}$, respectively) than those from Sicily (mean TL: 180 and $202 \mathrm{~mm}$, respectively). Males from Israel also reached Maturity

Table 2. Results of ANCOVA model, for each sex, where total length $(\mathrm{mm})$ is the dependent variable and age (effect), area (covariate) and their interaction (age $\times$ area) are the independent variables. The overall model $F$-values and p-values are also represented for each sex

\begin{tabular}{|c|c|c|c|c|}
\hline Variable & Coefficients & SE & $t$-value & p-value \\
\hline \multicolumn{5}{|c|}{ Males $(N=193)$} \\
\hline Age & 16.167 & 1.557 & 10.383 & $<0.0001$ \\
\hline Area $^{a}$ & 10.922 & 5.572 & 1.960 & $<0.0001$ \\
\hline Age $\times$ Area & 12.140 & 2.070 & 5.864 & 0.051 \\
\hline Constant & 82.301 & 4.862 & 16.927 & $<0.0001$ \\
\hline \multicolumn{5}{|c|}{ Model $F_{3,189}\left(\mathrm{R}^{2}=0.781\right)=192.07, \mathrm{p}$-value $<0.0001$} \\
\hline \multicolumn{5}{|c|}{ Females $(\mathrm{N}=\mathbf{2 3 8})$} \\
\hline Age & 20.760 & 1.500 & 13.843 & $<0.0001$ \\
\hline Area $^{a}$ & 19.264 & 5.212 & 3.696 & $<0.0001$ \\
\hline Age $\times$ Area & 6.627 & 1.741 & 3.806 & $<0.0001$ \\
\hline Constant & 75.411 & 4.691 & 16.074 & $<0.0001$ \\
\hline \multicolumn{5}{|c|}{ Model $F_{3,234}\left(\mathrm{R}^{2}=0.870\right)=412.67, \mathrm{p}$-value $<0.0001$} \\
\hline \multicolumn{5}{|c|}{${ }^{\mathrm{a}}$ 1: Sicily, 0: Israel } \\
\hline
\end{tabular}




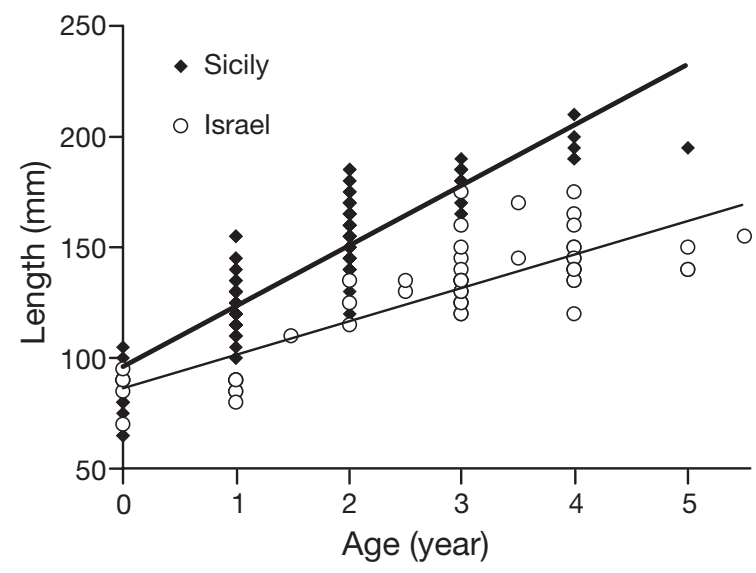

Fig. 2. Mullus barbatus. Growth patterns in males from Israel and Sicily. Curves represent regression lines for prediction of length by age (details in Table 2). ' 0 ': $<1 \mathrm{yr}$ of age $\left(\mathrm{R}^{2}\right.$ values and statistical significance of each fit are presented in Table 2 ; slopes and intercepts can be derived from Table 2)

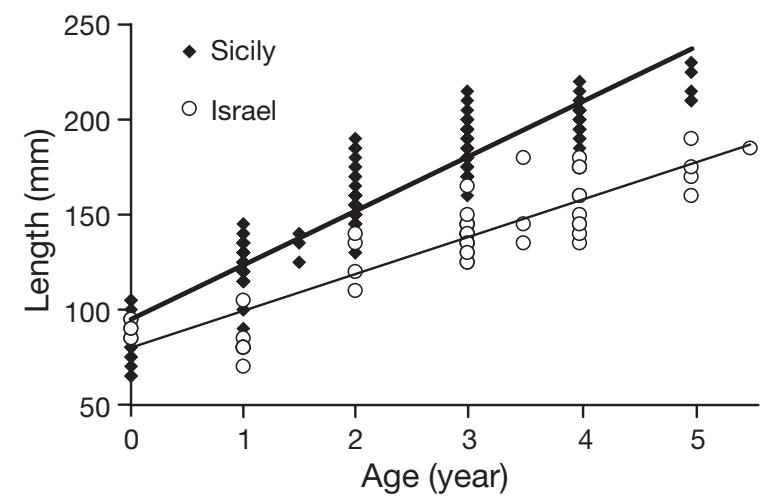

Fig. 3. Mullus barbatus. Growth patterns in females from Israel and Sicily. Curves represent regression lines for prediction of length by age (details in Table 2$)$. ' 0 ': $<1 \mathrm{yr}$ of age $\left(\mathrm{R}^{2}\right.$ values and statistical significance of each fit are presented in Table 2; slopes and intercepts can be derived from Table 2)

Stage 2 at a smaller size (mean TL: 133 mm) than those from Sicily (mean TL: $164 \mathrm{~mm}$ ), and those reaching Maturity Stage 3 tended to be smaller along the Israeli coast (mean TL: $152 \mathrm{~mm}$ ) than conspecifics recorded in Sicily (mean TL: $180 \mathrm{~mm}$ ).

\section{DISCUSSION}

As a first of its kind, the present study set out to systematically investigate Por's (1989) hypothesis of 'Levantine nanism' in a bony fish, Mullus barbatus. The present findings clearly demonstrate that $M$. barbatus fished on the Mediterranean continental shelf of Israel are significantly smaller than their conspecifics of the same age and sex from the Strait of Sicily (Tables 1 \& 2).

A recent allusion to nanism can be found in the work of Aharonov \& Goren (2001), who pointed out that females of dusky groupers Epinephelus marginatus from the Mediterranean coast of Israel reached sexual maturity at a younger age and shorter length than conspecifics from other sites in the Mediterranean. However, according to their calculations, the growth rate of their fish proved similar to those in the western basin (Boucheraue et al. 1999). They concluded, therefore, that their findings did not correspond with the theory of Levantine nanism.

How, then, do we explain the phenomenon of Levantine nanism? Three main environmental factors differentiate between the eastern and western Mediterranean - productivity, temperature and salinity.

\section{Productivity}

Primary productivity is significantly lower in the eastern Mediterranean compared with the central and western parts of this sea. Average chlorophyll concentrations for the euphotic zone in the

Table 3. Mullus barbatus. Mean sizes (total length in $\mathrm{mm}$ ) and $95 \%$ confidence intervals (CI) for males (M) and females (F) from Israel (I) and Sicily (S) in Maturity Stages 2 (gonads are distinguished easily) and 3 (gonads are matured). For sample sizes $<3$, actual minimum and maximum values are presented

\begin{tabular}{|c|c|c|c|c|c|c|}
\hline \multirow{2}{*}{$\begin{array}{l}\text { Maturity } \\
\text { stage }\end{array}$} & \multirow[t]{2}{*}{ Sex } & \multirow[t]{2}{*}{ Area } & \multirow[t]{2}{*}{$\mathrm{n}$} & \multirow[t]{2}{*}{ Mean } & \multicolumn{2}{|c|}{$-95 \% \mathrm{CI}-$} \\
\hline & & & & & Lower & Upper \\
\hline \multirow[t]{4}{*}{2} & F & I & 8 & 135.6 & 130.0 & 141.3 \\
\hline & & $\mathrm{S}$ & 99 & 179.8 & 175.1 & 184.5 \\
\hline & $\mathrm{M}$ & I & 12 & 132.9 & 126.9 & 138.9 \\
\hline & & $\mathrm{S}$ & 51 & 163.7 & 158.9 & 168.6 \\
\hline \multirow[t]{4}{*}{3} & F & I & 2 & 142.5 & $\min .138 .9$ & $\max .146 .1$ \\
\hline & & $\mathrm{S}$ & 5 & 202.0 & 187.0 & 217.0 \\
\hline & $\mathrm{M}$ & I & 10 & 152.0 & 145.0 & 159.0 \\
\hline & & $\mathrm{S}$ & 2 & 180.0 & $\min .169 .4$ & max. 190.6 \\
\hline
\end{tabular}
oceanic region (depth $<100 \mathrm{~m}$ ) off the Mediterranean coast of Israel are 0.06 to $0.12 \mathrm{mg} \mathrm{m}^{-3}$ (Berman et al. 1986) and 0.2 to $0.5 \mathrm{mg} \mathrm{m}^{-3}$ in the Strait of Sicily (Agostini \& Bakun 2002), with patches of elevated chlorophyll concentrations, e.g. along the Algerian coast, where chlorophyll concentrations sharply increase to $>0.5 \mathrm{mg} \mathrm{m}^{-3}$ (Martinez et al. 1990). Recent primary production studies (Moutin \& Raimbault 2002) indicated levels of 350 to $450 \mathrm{mg} \mathrm{C} \mathrm{m}^{-2} \mathrm{~d}^{-1}$ around the Strait of Sicily and $<150 \mathrm{mgC}^{-}$ $\mathrm{m}^{-2} \mathrm{~d}^{-1}$ in the Levant basin. The same authors reported a similar decrease in nutrient availability. Specifically, nitrate and phosphate concentrations in the surface layer 
( 0 to $100 \mathrm{~m}$ ) were, respectively, $1.2 \pm 1.4$ and $0.05 \pm$ $0.05 \mu \mathrm{M}$ in the western basin and $0.3 \pm 0.7$ and $0.01 \pm$ $0.02 \mu \mathrm{M}$ in the eastern basin. Herut et al. (2000) reported chl a concentrations at 2 fixed stations across the southeastern Mediterranean continental shelf and slope (120 and $400 \mathrm{~m}$ ) ranging between 0.003 and 0.415 $\mathrm{mg} \mathrm{m}^{-3}$. In terms of primary productivities, the values measured around the Strait of Sicily are, at least, more than twice those measured off the coast of Israel.

Occasionally, however, after storms in the Levant basin, nutrients on the shallow continental shelf reach the euphotic zone and temporarily increase primary productivity and influence the food web (Azov 1986). Also, Herut et al. (2000) reported distinct biomass phytoplankton peaks ( 30 $\mathrm{mg} \mathrm{chl} \mathrm{a} \mathrm{m}^{-3}$ in the upper $\left.120 \mathrm{~m}\right)$ following autumn and winter storms. These unpredictable changes can be expressed temporarily also in higher trophic levels, including the benthic invertebrates (small crustaceans, mollusks and polychaetes) that are the main food for Mullus barbatus (Ben-Eliyahu \& Golani 1990, Golani \& Galil 1991, Lythgoe \& Lythgoe 1992). Pianka (1970) suggested that in variable and unpredictable conditions (of food supply in the present study), the adaptation of the population is for r-selection, where development is fast, reproduction is early and body size is small. Our preliminary results (Table 3 ) that point to sexual maturation at smaller body size in the Levantine specimens may supply supportive evidence. Jobling (1996) stated that an r-strategist would be expected to mature early in life, develop rapidly, produce large numbers of offspring for a given body size and have maximum production of offspring at an early age. As a consequence, the organism allocates a large proportion of the available resources to reproductive activities.

Jobling (1996) also suggested that r-strategists would also be expected to have small body sizes. The special expression of r-strategy, as a possible outcome of an unpredictable environmental factor (in this case food supply) influencing a species, is demonstrated throughout all the year classes of Mullus barbatus.

In Year Class '0' (Table 1), Israeli specimens demonstrate larger size. Larger size may reflect a rapid growth rate, compared to that of Sicilian conspecifics, and thus the Israeli specimens gain maturity as early as possible. Yet larger size may also be achieved because Israeli fish have larger eggs and offspring hatch at a larger size. From Year Class '1' onward, growing pattern changes dramatically, as Sicilian specimens, male and females alike, are of larger body size than their Israeli conspecifics (Figs. 2 \& 3).

We therefore propose that, as suggested by Jobling (1996), after maturity is reached Mullus barbatus in the Levant basin also shifts energy from gaining body size and maturity to mainly reproduction at the expense of growth.

\section{Temperature}

The average higher water temperature in the southeastern Mediterranean may be another explanation for Levantine nanism. Mean surface water temperature in the Strait of Sicily (winter to summer) is 14 to $23^{\circ} \mathrm{C}$, and $13.8^{\circ} \mathrm{C}$ in the intermediate layer $(200 \mathrm{~m})$. Mean surface water temperature in the Levant is 16 to $26^{\circ} \mathrm{C}$ (in recent years maximum summer temperature measured at $20 \mathrm{~m}$ on the continental shelf off Israel exceeded $30^{\circ} \mathrm{C}$; E. Spanier \& O. Sonin pers. obs.), and $14.9^{\circ} \mathrm{C}$ in the intermediate layer (200 m) (Zenetos et al. 2002). Higher water temperature may cause more intensive metabolism (e.g. Jobling 1993) in the southeastern population, resulting in earlier sexual maturity and deceleration of growth.

Fishes in the Atlantic, such as the cod Gadus morhua, show faster growth when conditions are warmer (e.g. Campana et al. 1995). On the other hand, populations of Atlantic cod in colder areas at higher latitudes are larger and grow slowly. Some coral reef fish are larger in Hawaii (colder water) than their conspecifics in warmer water (Rainer Froese pers. comm. 2002). Charnov (1993) mentioned a similar trend in flatfish. At high temperature there will also be a decline in the rate of ingestion (Jobling 1993) that may result in smaller body size. Moreover, the rate of development (maturity stage) is generally found to increase when temperatures become higher (Jobling 1996).

It seems, however, that the differences in water temperature between the eastern and central Mediterranean are less dramatic than those involved in food supply. We suggest that the higher water temperature in the Levant may be a supplementary explanation for nanism at the most.

\section{Salinity}

Mean surface salinity in the Strait of Sicily is 37.5 and $38.6 \%$ at intermediate depth. Mean surface salinity in the Levant is 39 and $38.9 \%$ in the intermediate layer (Zenetos et al. 2002). Cotton et al. (2003) found some effect of salinity on growth of juvenile Black Sea bass Centropristis striata. However, the differences in salinities affecting body growth were greater by an order of magnitude (10 to $20 \%$ ) than in our case. Denson et al. (2003) reported a similar trend in growth affected by considerable salinity differences for juvenile cobia Rachycentron canadum. Since the differences between water salinities in the Levant and the Strait of Sicily are relatively small, we suggest that their effect on nanism is negligible. Another possible factor that may affect fish body size is not environmen- 
tal, but man-made fishing pressure (e.g. Jennings \& Polunin 1996).

Both populations have been exposed to very intensive fishing for many years, due to the traditional demands (and high prices) for this species. Fishing equipment is very much alike in the 2 areas. Both populations are exploited with the same fishing methodtrawling. Moreover, when trawl fisheries were established in Israel $50 \mathrm{yr}$ ago, Italian instructors from Sicily supervised the project (Schmida \& Ben-Yami 1968). The red mullet fishing grounds in the Strait of Sicily, which are utilized by the Italian trawl fleet, cover an area of about $12000 \mathrm{~km}^{2}$. Some 250 Italian trawlers operate within these grounds. Thus, every Italian trawler operates in an average of $48 \mathrm{~km}^{2}$ of fishing grounds per vessel. Along the coast of Israel, fishing grounds for red mullet are about $3300 \mathrm{~km}^{2}$; only 28 trawlers operate there - an average of $118 \mathrm{~km}^{2}$ of fishing grounds per vessel.

Therefore, the differences in body size between the Israeli and Sicilian populations of Mullus barbatus cannot be attributed to differences in fishing pressure. Considering all of the above parameters, temperature may only provide a minor explanation for Levantine nanism, and fishing pressure also seems to have a limited effect. Salinity appears to be insignificant in this context. Therefore, it is suggested that the foremost factor responsible for Levantine nanism is the scarcity and unpredictability of the food supply, resulting from the lower primary production and its influence on the food web.

Dwarfs are assumed to be faster growers. This may have implications regarding other populations' parameters, such as natural mortality, recruitment success and density dependence. Thus, the management of fish stocks in the Mediterranean must be addressed differently if nanism is at stake.

Similar studies are, therefore, recommended on other commercially important Mediterranean species. In addition, it would be interesting to investigate whether Levantine nanism is also found in Lessepsian migrants that entered the eastern Mediterranean through the Suez Canal and spread westward (Spanier \& Galil 1991).

Acknowledgements. This research was partially supported by a 1999 to 2001 grant from the Ministry of Science of the State of Israel (MOS) and the Consiglio Nazionale delle Ricerche (CNR) of the Republic of Italy to E. Spanier and D. Levi that enabled mutual visits by the Israeli and Italian scientists conducting the joint research project. We are grateful to Dr. D. Golani, Dr. M. Goren and H. Gordin, as well as 3 anonymous reviewers, for their useful comments on drafts of the manuscript. Thanks are due also to Dr. N. Barkan from the Department of Statistics, University of Haifa, for consultation on the statistics for the revised manuscript.

\section{LITERATURE CITED}

Agostini VN, Bakun A (2002) 'Ocean triads' in the Mediterranean Sea: physical mechanisms potentially structuring reproductive habitat suitability (with example application to European anchovy, Engraulis encrasicolus). Fish Oceanogr 11:129-142

Aharonov A, Goren M (2001) Aspects of reproductions and sex changes in Mediterranean groupers. In: Proceedings of the 14th symposium on the Mediterranean continental margins of Israel. University of Haifa, p 31-34 (in Hebrew)

Atkinson D (1994) Temperature and organism size-A biological low for ectotherms? In: Begon M, Fitter AH (eds) Advances in ecological research. Academic Press, London, p 1-58

Atkinson D, Sibly M (1997) Why are organisms usually bigger in colder environments? Making sense of the life history puzzle. Trends Ecol Evol 12:235-239

Azov Y (1986) Seasonal patterns of phytoplankton productivity and abundance in near shore oligotrophic water of the Levant Basin (Mediterranean). J Plankton Res 8:41-53

Ben-Eliyahu MN, Fiege D (1994) Polychaetes of the family Acoetide (=Polyodontidae) from the Levant and the Central Mediterranean with a description of a new species of Euarche. In: Daubin JC, Laubier L, Reish DJ (eds) Actes de la 4ème Conférence internationale des Polychètes. Mem Mus Nat Hist Nat (Fr) 162:145-161

Ben-Eliyahu MN, Golani D (1990) Polychaetes (Annelida) in the gut contents of goatfishes (Mullidae), with new Polychaete records for the Mediterranean coast of Israel and the Gulf of Eilat (Red Sea). PSZN I: Mar Ecol 11(3):193-205

Ben-Tuvia A (1983) The Mediterranean Sea. B. Biological aspects. In: Ketchum BH (ed) Estuaries and enclosed seas, ecosystems of the World. Elsevier, Amsterdam, p 239-251

Berman T, Azov Y, Schneller A, Walline P, Townsend DW (1986) Extent, transparency and phytoplankton distribution of the neritic waters overlaying the Israeli coastal shelf. Oceanol Acta 9:439-447

Berrigan D, Charnov EL (1994) Reaction norms for age and size at maturity in response to temperature: a puzzle for life historians. Oikos 70:398-414

Boucheraue JL, Body P, Chauvet C (1999) Growth of the dusky grouper, Epinephelus marginatus, in the natural marine reserve of Evezzi Islands, Corsica, France. Sci Mar 63:71-77

Campana SM, Mohn RK, Smith SJ, Chouinard GA (1995) Spatial implications of a temperature-based growth model for Atlantic cod (Gadus morhua) off the coast of Canada. Can J Fish Aquat Sci 52:2445-2456

Charnov EL (1993) Life history invariants - some explorations of symmetry in evolutionary ecology. Oxford University Press

Cingolani N, Coppola SR, Mortera J (1986) A qualitative system. II. Catch and fishing effort statistics. Quad Ist Ric Pesca Maritt 5 (1 Suppl, 1\&2 parte):XXVIII + 1-754

Cotton CF, Walker Rl, Recicar TC (2003) Effects of temperature and salinity on growth of juvenile Black Sea bass (Centropristis striata), with implications for aquaculture. N Am J Aquacult 65(4):330-338

Denson MR, Stuart KR, Smith TIJ, Weirich CR, Segars A (2003) Effects of salinity on growth, survival, and selected hematological parameters of juvenile cobia Rachycentron canadum. J World Aquac Soc 34(4):496-504

Dhillon RS, Fox MG (2004) Growth-independent effects of temperature on age and size at maturity in Japanese medaka (Oryzias latipes). Copeia 2004(1):37-45

Fredj G, Laubier L (1985) The deep Mediterranean benthos. In: 
Moraito-Apostolopoulu M, Kiortsis V (eds) Mediterranean marine ecosystems. Plenum Press, New York, p 109-145

Fredj G, Maurin C (1987) Les poissons dans la banque de données MEDIFAUNA. Application a l'étude des caractéristiques de la fauna ichthyologique Méditerranéenne. Cybium 11:217-299

Golani D (1996) The marine ichthyofauna of the eastern Levant-History, inventory and characterization. Isr J Zool 42:15-55

Golani D (2005) Checklist of the Mediterranean fishes of Israel. Zootaxa 947:1-90

Golani D, Darom D (1997) Handbook of the fishes of Israel. Keter, Jerusalem (in Hebrew)

Golani D, Galil B (1991) Trophic relationship of colonizing and indigenous goatfishes (Mullidae) in the eastern Mediterranean with special emphasis on decapod crustaceans. Hydrobiology 218:27-33

Goren E, Galil BS (1997) New records of deep-sea fishes from the Levant basin and a note on the deep-sea fishes of the Mediterranean. Israel Isr J Zool 43:197-203

Herut B, Almogi-Labin A, Jannink N, Gertman I (2000) The seasonal dynamics of nutrient and chlorophyll a concentrations on the SE Mediterranean shelf-slope. Oceanol Acta 23:771-782

Hilborn R, Walters JC (1992) Quantitative fisheries stock assessment, choice, dynamics and uncertainty. Chapman and Hall, London

Holden MJ, Raitt DFS (1974) Manual of fisheries science, Part 2. Methods of resources investigation and their application. FAO Fish Tech Pap 115(Rev. 1):1-214

IREPA (Istituto Ricerche Economiche per la Pesca e l'Aquacoltura) (2000a) Quarterly Italian fisheries bulletin, Year 6, No. 1, Period 01/2000-03/2000. IREPA, Salerno (in Italian)

IREPA (2000b) Quarterly Italian fisheries bulletin, Year 6, No. 2, Period 04/2000-06/2000. IREPA, Salerno (in Italian)

IREPA (2001a) Quarterly Italian fisheries bulletin, Year 6, No. 3, Period 07/2000-09/2000. IREPA, Salerno (in Italian)

IREPA (2001b) Quarterly Italian fisheries bulletin, Year 6, No. 4, Period 10/2000-12/2000. IREPA, Salerno (in Italian)

Jennings S, Polunin N (1996) Impacts of fishing on tropical reef ecosystems. Ambio 25(1):44-46

Jobling M (1993) Bioenergetics: feed intake and energy partitioning. In: Rankin JC, Jensen FB (eds) Fish ecophysiology. Chapman \& Hall, London, p 1-44

Jobling M (1996) Environmental biology of fishes. Chapman \& Hall, London

Laubier L (1966) Sur quelques Annélides de la région de Beyrouth. Am Univ Beirut Miscell Pap 5:9-22

Levi C (1957) Spongiaires des côtes d'Israel. Bull Res Counc Isr Sect B Biol Geol 6:201-202

Levi D, Andreoli MG, Arneri E, Giannetti G, Rizzo P (1994) Otolith reading as a tool for stock identification. Fish Res 20:97-107

Lythgoe J, Lythgoe G (1992) Fishes of the sea, the North Atlantic and Mediterranean. MIT Press, Cambridge, MA

Martinez RR, Arnone A, Velasquez Z (1990) Chlorophyll $a$ and respiratory electron transport system activity in microplankton from the surface waters of the western Mediterranean. J Geophys Res 95:1615-1622

Moutin T, Raimbault P (2002) Primary production, carbon export and nutrients availability in western and eastern Mediterranean Sea in early summer 1996 (MINOS cruise). J Mar Syst 33-34:273-288

Pérés JM, Picard J (1956a) Recherches sur les peuplements benthiques du seuil Siculo-Tunisian. Résultats scientifiques de la 'Calipso'. Ann Inst Oceanogr 32:23-264

Pérés JM, Picard J (1956b) Considérations sur l'étagement des formations benthiques. Recl Trav Stn Mar Endoume Fac Sci Mars 18 (Bull 11)

Pérés JM, Picard J (1956c) Notes préliminaries sur les réultats de la campagne de recherches benthiques de la Calipso dans la Méditerranée Nord-Orientale. Recl Trav Stn Mar Endoume Fac Sci Mars 18 (Bull 11)

Pérés JM, Picard J (1958) Recherches sur les peuplements benthiques de la Méditerranée Nord-Orientale. Ann Inst Oceanogr 34:214-291

Pianka ER (1970) On $r$ and $K$ selection. Am Nat 104:214-291

Por FD (1989) The legacy of Tethys - an aquatic biogeography of the Levant. Kluwer, Dordrecht

Quignard JP, Tomasi JA (2000) Mediterranean fish, biodiversity. Biol Mar Mediterr 7(3):1-66

Relini GJ, Bertrand J, Zamboni A (eds) (1999) Synthesis of the knowledge on bottom fishery resources in Central Mediterranean. Biol Mar Mediterr 6(Suppl 1):276-291

Ryan WBF (1966) Mediterranean Sea: physical oceanography. In: Fairbridge RW (ed) The encyclopedia of oceanography. Van Nostrand Reinhold, New York, p 492-493

Saurnia A (1973) La production primaire planctonique en Mediterranée. Newsl Coop Investig Mediterr Spec Issue 5:1-128

Schmida D, Ben-Yami M (1968) Trawl fisheries in Israel. Isr Fish Aquacult 1:54-61 (in Hebrew)

Sibly RM, Atkinson D (1994) How rearing temperature affects optimal adult size in ectotherms. Funct Ecol 8:486-493

Snovsky G, Shapiro J (eds) (1999) The fisheries and aquaculture of Israel 1999 in figures. The State of Israel, Ministry of Agriculture, Department of Fisheries, Tel-Aviv

Sonin O, Spanier E, Pisanty S (1996) Undersize fishes in the catch of the Israeli Mediterranean fisheries-Are there differences between shallow and deeper water? In: Steinberger Y (ed) Preservation of our world in the wake of change. Proceedings of the 6th international conference of the Israeli Society for Ecology and Environmental Quality Sciences, Vol. IB. ISEEQS, Jerusalem, p 449-454

Spanier E, Galil BS (1991) Lessepsian migration? A continuous biogeographical process. Endeavour 15(3):102-106

Stephen AC (1958) The sipunculids of the Bay of Haifa and neighborhood. Bull Res Counc Isr Sect B Biol Geol 7: 191-192

Tortonese E (1951) I caratteri biologici de Mediterraneo orientale e I problemi relativi. Arch Zool Ital Suppl 7:205-251

van der Have TM, de Jong G (1996) Adults size in ectotherms: temperature effects on growth and differentiation. J Theor Biol 183:329-340

Voliani A, Abella A, Auteri R (1998) Some considerations on the growth performance of Mullus barbatus. Cah Opt Mediterr 35:93-106

Whitehead PJ, Bauchot ML, Hureau JC, Nielsen J, Tortunese E (eds) (1986) Fishes of the north-eastern Atlantic and the Mediterranean, Vol. II. UNESCO, Paris

Wirssubski A (1953) On the biology and biotope of the red mullet. Bull Sea Fish Res Stn Isr 7:1-20

Zenetos A, Siokou-Frangou I, Gotsis-Skretas O, Groom S (2002) The Mediterranean Sea, blue oxygen-rich, nutrientpoor waters. Europe's biodiversity, biogeographical regions and seas. Seas around Europe. EEA (European Environment Agency), National Centre for Marine Research (NCMR), Copenhagen

Submitted: June 25, 2003; Accepted: February 12, 2007

Proofs received from author(s): July 20, 2007 